\title{
Enzyme Production by Induratia spp. Isolated from Coffee Plants in Brazil
}

\author{
Mônica Cristina Pereira Monteiro \\ https://orcid.org/0000-0002-5640-7622 \\ Dérica Gonçalves Tavares ${ }^{1}$ \\ https://orcid.org/0000-0002-3727-0173 \\ Eduardo Mateus Nery ${ }^{1}$ \\ https://orcid.org/0000-0002-0291-6878
}

\author{
Marisa Vieira de Queiroz ${ }^{2}$ \\ https://orcid.org/0000-0002-2280-4793 \\ Olinto Liparini Pereira ${ }^{3}$ \\ https://orcid.org/0000-0002-0274-4623
}

\author{
Patrícia Gomes Cardoso ${ }^{1^{*}}$ \\ https://orcid.org/0000-0002-0797-2502
}

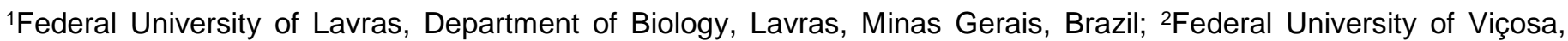
Department of Microbiology, Viçosa, Minas Gerais, Brazil; ${ }^{3}$ Federal University of Viçosa, Department of Phytopathology, Viçosa, Minas Gerais, Brazil.

Received: 2018.11.20; Accepted: 2020.02.07.

*Correspondence: patricia@ufla.br; Tel.: +55-35-38291883 (PGC)

\section{HIGHLIGHTS}

- Induratia spp. as enzyme producers.

- Extracellular hydrolases produced by endophytic fungi.

- I. coffeana isolated from organic coffee plantation.

- Phytase activity was present in all species of Induratia.

\begin{abstract}
Endophytic fungi belonging to the genus Muscodor now transferred to Induratia are known producers of bioactive volatile organic compounds (VOCs) with many industrial applications. However, the members of this genus have rarely been reported to produce non-volatile metabolites including enzyme. Enzymes of the endophytes are degraders of the polysaccharides available in the host plants and the knowledge of enzyme production by Induratia spp. may provide insights into their possible biotechnological applications. The aim of this study was to evaluate the activity of amylase, cellulase, lipase, pectinase, phytase, protease, endo $\beta-1,4$ glucanase and exo $\beta-1,4$ glucanase enzymes produced by fungi of the species Induratia coffeana, Induratia yucatanensis and Induratia sp. isolated from organic coffee plants. All Induratia spp. were able to produce the extracellular enzymes cellulase, pectinase, protease, and phytase. Eight fungi were able to produce lipase and four produced amylase. The specific activity of endo $\beta-1,4$ glucanase and exo $\beta-1,4$ glucanase enzymes were detected for 9 and 8 endophytic fungi, respectively. This work demonstrated for the first time, the array of enzymes produced by Induratia spp. isolated from Coffea arabica in organic systems in Brazil.
\end{abstract}

Keywords: extracellular enzymes; endophytic fungi; cellulases; Muscodor. 


\section{INTRODUCTION}

The term "endophytes" includes microorganisms that grow intracellularly for all or part of their life cycle in the tissues of plants, without causing disease to the host [1]. These microorganisms protect their hosts against insect pests and pathogenic microorganisms and provide several benefits to the host plant $[2,3]$. The endophytic fungi are associated with economically important plants including genus Coffea sp. [4-9]. The crop coffees in Brazil have great importance socioeconomically, being the country the largest producer and exporter of coffee in the world [10]. The great diversity of fungi associated with these plants may be highly relevant, since endophytic fungi are producers of metabolites. Several studies have demonstrated the diversity of endophytes from Coffea arabica, but there are very few studies on the same in the varieties of organic crops [4,5]. This crop system has increased due to the growing demand and high consumption of healthy foods that contain compounds with antioxidant potential, which have been associated with the reduction of chronic diseases [11].

In recent years, considerable attention has been given to the screening, isolation, and characterization of new bioactive secondary metabolites from endophytic fungi and metabolites with potential for use in industry, agriculture, and medicine [12-18]. Like other organisms invading plant tissues, endophytic fungi produce extracellular hydrolases as a resistance mechanism against pathogenic invasion and to obtain nutrition from their host [19]. Endophytic fungi occupy a relatively unexplored area in microorganism isolation, and thus represent a new source for obtaining enzymes with different potentials. Studies have shown that endophytic fungi can produce amylases, lipases, proteases, pectinases, and cellulases [19-23].

Recently, Samarakoon and coauthors [24] showed that Muscodor species, a biotechnologically important genus that produce antibiotic volatile secondary metabolites, have affinities to the xylarialean genera Emarcea and Induratia. They used polyphasic taxonomic and transferred all Muscodor species to Induratia. A study from our group showed that volatile compounds produced by Induratia spp. including the species Induratia coffeana isolated from an organic coffee plantation, have antagonistic activity against pathogenic fungi of coffee and other plants of agricultural interest [25]. Therefore, we sought to screen the fungi present in these plants to assess their biotechnological potential as producers of extracellular amylase, cellulase, lipase, pectinase, phytase, protease, endo $\beta-1,4$ glucanase, and exo $\beta-1,4$ glucanase.

\section{MATERIAL AND METHODS}

\section{Microorganisms}

The nine fungi used in this study were isolated from fresh and healthy tissues of organic coffee plantations (Coffea arabica) from Zona da Mata region, Viçosa municipality, Minas Gerais, Brazil and identified as I. coffeana (CML4009, CML4010, CML4011, CML4012), Induratia sp. (CML4013, CML4015) and Induratia yucatanensis (CML4014, CML4016, CML4017). The fungi were selected for their ability to grow in the presence of volatile organic compounds (VOCs) produced by Induratia alba CZ620 as reference strain [26]. These fungi belong to the collection of the Prospection and Genetic of filamentous fungi laboratory (Biogen) at the Federal University of Lavras, Brazil and were deposited in the Mycological Collection of Lavras (CML) at the Department of Phytopathology at the Federal University of Lavras, Brazil. The isolates were reactivated on potato dextrose agar medium (PDA) and were incubated at $25{ }^{\circ} \mathrm{C}$ for 7 days.

\section{Enzyme activity}

The ability of endophytic fungi to produce amylases, cellulases, lipases, pectinases, phytase, and proteases were qualitatively assessed on specific indicative solid media. The isolates were cultured on (PDA) medium for 7 days and transferred to $5 \mathrm{~mm}$ mycelial plugs on the center of the Petri dishes containing the solid medium with specific substrates to each enzyme.

\section{Lipase}

The fungi were grown in a medium containing $1.0 \%$ tween 20 as substrate, $1.0 \%$ peptone, $0.5 \% \mathrm{NaCl}$, $0.01 \% \mathrm{CaCl}_{2} .2 \mathrm{H}_{2} \mathrm{O}$ and $1.8 \%$ agar. They were cultured at $30{ }^{\circ} \mathrm{C}$ for 7 days.

\section{Amylase}

Amylase activity was assessed by growing the fungi in soluble $0.2 \%$ starch, $0.1 \%$ glucose, $0.01 \%$ yeast extract, $0.05 \%$ peptone and $1.6 \%$ agar. The plates were incubated at $28{ }^{\circ} \mathrm{C}$ for 7 days. 


\section{Protease}

For estimating the protease activity the medium contained, $1.0 \%$ gelatin, $1.0 \%$ skim milk, $400 \mathrm{~mL}$ sodium citrate buffer $0.1 \mathrm{M}$ and $1.8 \%$ agar. The fungi were incubated at $25{ }^{\circ} \mathrm{C}$ for 7 days.

\section{Phytase}

The fungi were cultured in medium containing $0.5 \%$ phytic acid $\left(\mathrm{C}_{6} \mathrm{H}_{18} \mathrm{O}_{24} \mathrm{P}_{6}\right), 0.3 \% \mathrm{NaNO}_{3}, 0.05 \%$ $\mathrm{MgSO}_{4} .7 \mathrm{H}_{2} \mathrm{O}, 0.05 \% \mathrm{KCl}, 0.012 \% \mathrm{FeSO}_{4}, 0.06 \% \mathrm{CaCl}_{2}, 0.01 \% \mathrm{ZnSO}_{4}$ and $1.5 \%$ agar. The fungi were cultured for 7 days at $25^{\circ} \mathrm{C}$.

\section{Pectinase}

The fungi were cultured in solid mineral medium buffered $\left(0.2 \% \mathrm{KH}_{2} \mathrm{PO}_{4}, 0.7 \% \mathrm{~K}_{2} \mathrm{HPO}_{4}, 0.1 \%\right.$ $\left(\mathrm{NH}_{4}\right)_{2} \mathrm{SO}_{4}, 0.1 \% \mathrm{MgSO}_{4} .7 \mathrm{H}_{2} \mathrm{O}, 0.06 \%$ yeast extract, $0.3 \%$ citrus pectin, $1.3 \%$ agar). The fungi were inoculated and maintained at $25^{\circ} \mathrm{C}$ for 7 days. After this time, mycelial disks were removed and transferred to the buffered medium Mac Ilvaine (1.3\% agar, $0.25 \%$ citrus pectin, the solution $369 \mathrm{~mL} \mathrm{C}_{6} \mathrm{H}_{8} \mathrm{O}_{7}, 0.1 \mathrm{M}$, the solution $631 \mathrm{~mL} \mathrm{Na} \mathrm{HPO}_{4}, 0.2 \mathrm{M}$ ) and, then incubated at $40{ }^{\circ} \mathrm{C}$ for 48 hours.

\section{Cellulase}

The medium for cellulose production consisted of the following: $0.2 \% \mathrm{NaNO}_{3}, 0.1 \% \mathrm{~K}_{2} \mathrm{HPO}_{4}$, and $0.05 \%$ $\mathrm{KCl}, 0.02 \%$ peptone, $0.2 \%$ Carboxymethylcellulose (CMC) and $1.7 \%$ agar. The plates were incubated at $28{ }^{\circ} \mathrm{C}$ for 7 days. After the incubation period, the plate was flooded with iodine $(2.0 \mathrm{~g} \mathrm{KI}$ and $1.0 \mathrm{~g}$ iodine in $300 \mathrm{~mL}$ distilled water) for 3 to $5 \mathrm{~min}$. The formation of a clear halo around the colonies was considered a positive result, indicating the presence of the given enzyme. The calculation of enzymatic index (El) was performed by the median diameter ratio degradation halo and the average diameter of the colony as proposed by Hankin and Anagnostakis [27].

\section{Enzyme activity assays for endo B-1, 4 glucanase and exo B-1, 4 glucanase}

The medium for cellulase production consisted of the following reagents: $0.2 \% \mathrm{NaNO}_{3}, 0.1 \% \mathrm{~K}_{2} \mathrm{HPO}_{4}$, $0.05 \% \mathrm{KCl}, 0.02 \mathrm{~g}$ of peptone, and $0.2 \%$ of different inducers (Carboxymethylcellulose (CMC) and Avicel were used as inducers to produce endoglucanase and exoglucanase, respectively). Cultivation was conducted in $250 \mathrm{~mL}$ Erlenmeyer flasks containing $50 \mathrm{~mL}$ of production medium with the respective inducers. The Erlenmeyer flasks were incubated in a rotary shaker at $28{ }^{\circ} \mathrm{C}$ and $150 \mathrm{rpm}$, for 12 days. After the incubation period, the content of each flask was centrifuged, and the enzymatic activities were determined. The enzymes in this study were analyzed according to Miller [28] with modifications. Endoglucanase assays were performed in reaction tubes containing $125 \mu \mathrm{L}$ of $2 \% \mathrm{CMC}$ solution in $50 \mathrm{mM}$ sodium citrate buffer $(\mathrm{pH} 4.8)$ with $125 \mu \mathrm{L}$ of the enzymatic supernatant. The tubes were incubated at $50^{\circ} \mathrm{C}$ for $10 \mathrm{~min}$, and then $250 \mu \mathrm{L}$ of DNS (3.5-dinitrosalicilic acid) was added to stop the reaction. The exoglucanase assays were performed according to Lever [29] with modifications. The assays were conducted in reaction tubes containing $450 \mu \mathrm{L}$ of $1 \%(\mathrm{w} / \mathrm{v})$ Avicel, respectively, in $0.05 \mathrm{mM}$ sodium acetate buffer, $\mathrm{pH} 5.0$, with $50 \mu \mathrm{L}$ of crude enzyme solution. The tubes were incubated at $50{ }^{\circ} \mathrm{C}$ for $30 \mathrm{~min}$. To measure the glucose released, $1 \% \rho$-hydroxybenzoic acid hydrazide (PAHBAH) was added. The readings were performed in spectrophotometer at $540 \mathrm{~nm}$. One unit $(\mathrm{U} / \mathrm{mL})$ of enzyme activity was defined as the amount of enzyme that produces $1 \mu \mathrm{mol}$ of glucose per minute under the assay conditions.

\section{Protein determination}

Protein concentrations were determined by the Bradford method [30], using bovine serum albumin (BSA) as standard.

\section{Statistical analysis}

The experiments were performed in triplicate and results were submitted to analysis of variance using the R Statistics program, and the means were compared using the Scott and Knott test at $p<0.05$ level of significance [31]. 


\section{RESULTS}

The nine Induratia spp. were subjected to extracellular enzyme production in solid media. According to the methodology employed, some isolates revealed a significant zone of degradation of substrate while others showed less, indicating different levels of extracellular enzyme production. The hydrolysis halo diameter that permits the rapid and simple screening of large populations of fungi for the presence or absence of specific enzymes is useful in the selection of strains with high polysaccharide levels [32]. Eight fungi produced lipase, four produced amylase, and all species tested produced protease, phytase, pectinase, and cellulase (Table 1). Fungi of the genus Induratia such as I. coffeana, a species isolated from leaves and stems from coffee plants in Brazil, are described for the first time as producers some enzymes.

Table 1.Production of enzymes by endophytic fungi of the genus linduratia expressed as an enzymatic index in solid culture media.

\begin{tabular}{lllllll}
\hline Endophytic fungi & Cellulase & $\begin{array}{l}\text { Pectinas } \\
\text { e }\end{array}$ & Phytase & Lipase & Amylase & Protease \\
\hline l. coffeana (CML4009) & $2.7 \pm 0.5^{\mathrm{b}}$ & $1.8 \pm 0.3^{\mathrm{b}}$ & $4.4 \pm 0.5^{\mathrm{a}}$ & - & $2.1 \pm 0.1^{\mathrm{a}}$ & $1.3 \pm 0.0^{\mathrm{a}}$ \\
l. coffeana (CML4010) & $2.3 \pm 0.1^{\mathrm{c}}$ & $2.0 \pm 0.1^{\mathrm{a}}$ & $4.5 \pm 0.0^{\mathrm{a}}$ & $1.0 \pm 0.0^{\mathrm{c}}$ & - & $1.2 \pm 0.0^{\mathrm{a}}$ \\
l. coffeana (CML4011) & $2.1 \pm 0.0^{\mathrm{c}}$ & $2.1 \pm 0.2^{\mathrm{a}}$ & $3.3 \pm 0.9^{\mathrm{a}}$ & $2.3 \pm 0.4^{\mathrm{b}}$ & - & $1.3 \pm 0.3^{\mathrm{a}}$ \\
l. coffeana (CML4012) & $1.5 \pm 0.2^{\mathrm{c}}$ & $2.1 \pm 0.1^{\mathrm{a}}$ & $2.6 \pm 0.8^{\mathrm{a}}$ & $1.0 \pm 0.0^{\mathrm{c}}$ & $2.2 \pm 0.4^{\mathrm{a}}$ & $1.3 \pm 0.0^{\mathrm{a}}$ \\
Induratia sp. (CML4013) & $1.7 \pm 0.0^{\mathrm{c}}$ & $2.3 \pm 0.1^{\mathrm{a}}$ & $3.2 \pm 0.7^{\mathrm{a}}$ & $1.9 \pm 0.1^{\mathrm{c}}$ & $1.9 \pm 0.0^{\mathrm{a}}$ & $1.6 \pm 0.1^{\mathrm{a}}$ \\
Induratia sp. (CML4015) & $4.0 \pm 1.0^{\mathrm{a}}$ & $2.0 \pm 0.1^{\mathrm{a}}$ & $2.9 \pm 1.2^{\mathrm{a}}$ & $1.0 \pm 0.0^{\mathrm{c}}$ & - & $1.3 \pm 0.1^{\mathrm{a}}$ \\
l. yucatanensis (CML4014) & $1.4 \pm 0.3^{\mathrm{c}}$ & $1.9 \pm 0.2^{\mathrm{b}}$ & $3.5 \pm 0.4^{\mathrm{a}}$ & $2.7 \pm 0.0^{\mathrm{a}}$ & $2.0 \pm 0.2^{\mathrm{a}}$ & $1.5 \pm 0.2^{\mathrm{a}}$ \\
l. yucatanensis (CML4016) & $1.8 \pm 0.2^{\mathrm{c}}$ & $1.7 \pm 0.2^{\mathrm{b}}$ & $3.7 \pm 1.2^{\mathrm{a}}$ & $1.0 \pm 0.0^{\mathrm{c}}$ & - & $1.2 \pm 0.0^{\mathrm{a}}$ \\
l. yucatanensis (CML4017) & $1.7 \pm 0.1^{\mathrm{c}}$ & $1.9 \pm 0.2^{\mathrm{b}}$ & $3.2 \pm 1.2^{\mathrm{a}}$ & $1.0 \pm 0.0^{\mathrm{c}}$ & - & $1.2 \pm 0.1^{\mathrm{a}}$ \\
\hline
\end{tabular}

Data are expressed as mean of the repetitions \pm standard deviation. Means with different letters are significantly different at $p<0.005$.

I. yucatanensis (CML4014) was the highest producer of lipase activity with El of 2.7 differing statistically from the other isolates (Table 1). The lipase activity suggests that Induratia spp. possesses the ability to use fat as energy source and to live in association with oilseeds. Fungal lipases stand out as the major sources of the enzyme because of their catalytic activity, low cost of production numerous, industrial applications and relative ease in genetic manipulation [33]. Studies have been carried out evaluating lipase activity. Nwuche and Ogbonna (2011) [34] evaluated twelve lipase producing strains belonging to genera Aspergillus, Penicillium, Trichoderma and Mucor isolated from palm oil mill effluent composts. Aspergillus $\mathrm{sp}$. was the most frequently isolated fungus, but the highest lipase producing strains belong to the Trichoderma genus. Another study was carried out evaluating the immobilization of lipases produced by the endophytic fungus Cercospora kikuchii on chitosan microparticles [35]. Immobilization strategy was the most important factor to attain active and stable immobilized lipases technology for a wide range of industrial applications, mainly due the simplicity of the process involved in support production. The growing demand for lipases has stimulated prospecting for novel lipases from novel sources for new areas of application. Future studies on fungi of the Induratia genus might lead to the discovery of novel lipases with potential in variety of applications.

All Induratia spp. secreted proteases showing El ranges from 1.2 to 1.6 that did not differ statistically from each other (Table 1). Proteases are one of the largest and most diverse families of enzymes known to catalyze the addition of water across amide (and ester) bonds to cleave the carbonyl carbon of the scissile bond by a reaction involving nucleophilic attack. Proteolytic enzymes are very important in digestion as they breakdown peptide bonds in protein-rich foods to liberate amino acids needed by the body. Microbial proteases are leaders of the industrial enzyme market worldwide and account for numerous applications in a variety of industries [36]. There is growing interest in proteases with a wider spectrum of biological properties and industrial applications. In this context Induratia spp. can be industrially exploited to synthesize this enzyme. Strain improvement studies can also be carried out to enhance enzyme production.

Amylolytic activity was observed in I. coffeana (CML4009, CML4012), I. yucatanensis (CML4014) and Induratia sp. (CML4013) showing El ranges between 1.9 to 2.2 that did not differ statistically from each other. Amylases are starch-degrading enzymes that catalyze the hydrolysis of internal glycosidic bonds in polysaccharides with the retention of anomeric configuration in the products. Fungal amylases have been widely used for industrial production due to their cost effectiveness, consistency, ease of production, process modification, and optimization [37]. Most of the amylases have been produced from soil fungi [38] and very few reports are available on the industrial application of amylases from endophytic fungi. Thus, our work describes for the first time, amylase production by Induratia spp. The amylolytic potential of these 
endophytes may help them degrade starch, which is available when the plant senesces. There is enormous interest in amylases from new sources with better biological properties, because of the increasing demand for these enzymes used in numerous applications in various industries.

Phytase activity was present in all species of Induratia with EI ranges between 2.6 to 4.5 (Table 1). In numerical terms, I. coffeana (CML4010) was the highest producer of phytase. Our group described the optimization of some culture parameters to achieve high enzymatic production by this endophytic fungus with an increase of 11 fold in the specific activity [39]. Microorganisms are the main sources of phytases, but commercial phytases are produced by a limited number of microorganisms, which justify the importance of searching for new fungal strains that are phytase producers. This enzyme is used as a feed additive due to the lack of adequate levels of phytase enzyme in the gastrointestinal tracts of the monogastric animals like poultry, pigs, and fishes. Phosphate supplementation is required for the optimal growth of animals, but they are unable to efficiently utilize phytate phosphorus from major ingredients of animal feed (cereal grains and oilseeds) [40]. Phytase catalyzes the dephosphorylation of phytate to inositol and orthophosphate [41]. Due to immense industrial and environmental implication of phytases, there is ongoing interest in isolation of new fungal strains producing phytase and the optimization of this enzyme.

The isolates I. coffeana (CML4010, CML4011, CML4010) and Induratia sp. (CML4015, CML4013) showed pectinase activity with the highest El and did not differ statistically among them (Table 1). Microorganisms, isolated from different materials, have been screened for their ability to produce pectinases, especially fungi. Pectic enzymes are induced in the presence of pectic substances and are used extensively for various industrial applications and new applications are emerging [42]. Pectin lyase and polygalacturonase enzymes were synthesized by the fungi of the genus Moniliella and Penicillium isolated from decaying vegetable and soil utilizing as substrate a mixture of orange bagasse, sugar cane bagasse and wheat bran by solid-state fermentation [43]. Pectinases are important in the phytopathologic processes also, plant-microbe symbiosis, and in the decomposition of dead plant material by both pathogenic and endophytic fungi. If Induratia spp. can degrade pectic substances, this implies that this genus is likely to be a latent pathogen, since a degradation of host tissue generally begins with the production of pectinolytic enzymes, which are the major enzymes involved in plant attacks [44]. Hypothesize that the fungal endophyte-plant host interaction is characterized by equilibrium between fungal virulence and plant defense and if this balance is disturbed by either a decrease in plant defense or an increase in fungal virulence, disease develops. However, the main consideration in this work opens a new perspective for the study of Induratia species for the production and industrial application of these enzymes, since the production cost is high due to either low activity or the instability of the enzyme at high temperatures for longer duration.

Regarding cellulase activity, Induratia sp. (CML4015) showed larger El of 4.0 compared to other isolates of the same plants (Table 1). Cellulases are the third most industrially significant enzymes on the global market after amylases and proteases [45]. Enzymatic hydrolysis of cellulosic biomass offers an attractive alternative for the generation of sugars, which can serve as the raw materials in various economically relevant processes, such as cotton processing, paper recycling, juice extraction, enzymatic detergents, and animal food additives. The genera Aspergillus, Trichoderma, Humicola, Penicillium, Fusarium, and Phanerochaete are widely used in industrial enzyme production [23]. However, the high production cost and the low yield of cellulase are still the major constraints in the economics of the process, and the discovery of novel fungal species secreting cellulases is still an emerging area of research to develop economically competitive bioprocess strategies applicable on a large scale [46]. An interesting observation in our study is that Induratia sp. (CML4015) produced cellulases and pectinases suggesting that it is bioactive (obtaining nutrients from its hosts) and bio-resistant against pathogenic microbial infection.

Tests on solid media permit the rapid screening for the presence or absence of extracellular enzymes. Although we screened for six important enzymes in this study, we focused on endo- $\beta 1,4$ glucanase and exo $\beta-1,4$ glucanase activity. Cellulolytic enzymes have biotechnological applications in the food, pharmaceutical, environmental, and agricultural industries [47]. Enzymatic hydrolysis of cellulose includes the synergistic activity of a cellulolytic complex, usually from fungi, consisting of endoglucanases, exoglucanases, and $\beta$-D-glucosidase [48].

Analysis of the values obtained in the production of endo $\beta-1,4$ glucanase revealed that all fungi were able to produce this enzyme (Table 2). I. coffeana (CML4011) and I. yucatanensis (CML4014) were the best producers compared to the other fungi, with specific activity of $11.9 \mathrm{U} / \mathrm{mg}$ and $10.0 \mathrm{U} / \mathrm{mg}$, respectively. Regarding the production of exo $\beta-1,4$ glucanase, I. coffeana (CML4012) and I. yucatanensis (CML4017) were the best producers with values of $6.70 \mathrm{U} / \mathrm{mg}$ and $6.55 \mathrm{U} / \mathrm{mg}$, respectively (Table 2). No specific activity was detected for fungi I. coffeana (CML4009), despite showing positive production in total cellulase. This can be explained by the variety of enzymes that comprise the cellulolytic complex that act together to degrade cellulose. Besides, the method of selection of enzyme-producing fungi using the degradation halo 
and subsequent calculation of enzymatic index merely allows rapid observation of positive and negative results, but does not provide details regarding the intensity of production [49].

Table 2. Total activity $(\mathrm{U} / \mathrm{mL})$ and specific enzymatic activity of endoglucanase and exoglucanase $(\mathrm{U} / \mathrm{mg})$ of endophytic fungi.

\begin{tabular}{lclll}
\hline & \multicolumn{2}{l}{ Endo $\boldsymbol{\beta}-\mathbf{1 , 4}$ glucanase } & \multicolumn{2}{l}{ Exo $\boldsymbol{\beta}-\mathbf{1 , 4}$ glucanase } \\
\cline { 2 - 5 } Endophytic fungi & $\begin{array}{l}\text { Total activity } \\
(\mathbf{U} / \mathbf{m L})\end{array}$ & $\begin{array}{l}\text { Specific } \\
\text { activity } \\
(\mathbf{U} / \mathbf{m g})\end{array}$ & $\begin{array}{l}\text { Total activity } \\
(\mathbf{U} / \mathbf{m L})\end{array}$ & $\begin{array}{l}\text { Specific } \\
\text { activity }(\mathbf{U} / \mathbf{m g})\end{array}$ \\
\hline l. coffeana (CML4009) & $0.63 \pm 0.40^{\mathrm{b}}$ & $1.99 \pm 1.33^{\mathrm{c}}$ & - & \\
l. coffeana (CML4010) & $1.19 \pm 0.45^{\mathrm{a}}$ & $5.58 \pm 0.38^{\mathrm{b}}$ & $0.15 \pm 0.10^{\mathrm{b}}$ & $1.65 \pm 0.39^{\mathrm{b}}$ \\
I. coffeana (CML4011) & $1.43 \pm 0.16^{\mathrm{a}}$ & $11.9 \pm 1.27^{\mathrm{a}}$ & $0.15 \pm 0.21^{\mathrm{b}}$ & $0.90 \pm 1.27^{\mathrm{b}}$ \\
l. coffeana (CML4012) & $0.53 \pm 0^{\mathrm{b}}$ & $4.33 \pm 0.17^{\mathrm{b}}$ & $1.15 \pm 0.38^{\mathrm{a}}$ & $6.70 \pm 2.37^{\mathrm{a}}$ \\
Induratia sp. (CML4013) & $0.33 \pm 0.09^{\mathrm{b}}$ & $2.71 \pm 0.83^{\mathrm{c}}$ & $0.15 \pm 0.19^{\mathrm{b}}$ & $0.70 \pm 0.98^{\mathrm{b}}$ \\
Induratia sp. (CML4015) & $0.80 \pm 0.37^{\mathrm{b}}$ & $6.55 \pm 2.96^{\mathrm{b}}$ & $0.25 \pm 0.33^{\mathrm{b}}$ & $1.45 \pm 1.79^{\mathrm{b}}$ \\
l. yucatanensis (CML4014) & $1.19 \pm 0.29^{\mathrm{a}}$ & $10.0 \pm 2.96^{\mathrm{a}}$ & $0.40 \pm 0.20^{\mathrm{b}}$ & $2.30 \pm 1.12^{\mathrm{b}}$ \\
l. yucatanensis (CML4016) & $0.77 \pm 0.33^{\mathrm{b}}$ & $5.99 \pm 2.38^{\mathrm{b}}$ & $0.35 \pm 0.33^{\mathrm{b}}$ & $2.45 \pm 2.34^{\mathrm{b}}$ \\
l. yucatanensis (CML4017) & $0.90 \pm 0.61^{\mathrm{b}}$ & $7.07 \pm 5.07^{\mathrm{b}}$ & $1.2 \pm 0.19^{\mathrm{a}}$ & $6.55 \pm 1.35^{\mathrm{a}}$ \\
\hline
\end{tabular}

Data are expressed as mean of the repetitions \pm standard deviation. Means with different letters are significantly different at $p<0.005$.

Fungi belonging to Induratia genus are promising agents for biological control. Species display a sterile mycelium and emits a mixture of volatile organic compounds that inhibit or kill a broad range of pathogenic microorganisms and insects. Studies report the use of these compounds in the control of post-harvest diseases and soil microfumigation [26,50-58]. In a previous study, our group reported that the volatile compounds produced by Induratia spp. isolated from C. arabica showed antimicrobial action against Aspergillus ochraceus, Fusarium verticillioides, F. oxysporum, F. solani, F. verticillioides, Rhizoctonia solani, Phoma sp., Botrytis cinerea, Cercospora coffeicola, and Pestalotia longisetula [25]. I. coffeana was described by Hongsanan and coauthors [59]. To our knowledge, this study is one of the few reporting the enzyme activity of endophytic species of Induratia genus isolated from organic coffee plants. The ability to penetrate and colonize a selected plant cell using extracellular enzymes is a common trait of endophytic fungi. This ability may provide important mechanisms to protect them against invading pathogens, obtain nutrition from the host plant, or to become latent pathogens in their natural environment [60]. However, the members of this genus are poorly explored for the production of other primary and secondary metabolites. Therefore is interesting to evaluate the production of enzymes by Induratia spp. since these microorganisms can represent a new source for obtaining enzymes with different potentialities. In addition, the knowledge of enzyme production by endophytic fungi may provide insights into their possible biotechnological applications and provide an idea about their life cycles within the plant tissues.

\section{CONCLUSION}

Endophytes constitute a novel and important source of active substances that can be employed in different biotechnological industries. Considering the results of this study, it was concluded that the evaluated endophytic species of Induratia isolated from organic coffee plants have potential in the production of extracellular enzymes to biodegrade different polysaccharides. Studies of endophytic fungi, especially of new species, are interesting, since the endophytic fungi present potential for exploration. Due to the limited number of studies demonstrating the enzymatic activity of endophytic fungi, mainly of the Induratia genus, this work opens a new perspective for the study of these species for the production and industrial application of these enzymes. Screening for new producers of novel and industrially useful enzymes is of great interest for biotechnology research. Investigators in Brazil should further explore the potential to generate new enzymes from microbial sources, as this country has a continental area that includes hundreds of plant species with diverse endophytes.

Funding: This research was funded by Foundation of Research Support of Minas Gerais State (FAPEMIG), grant number CBB-RED00005/14.

Acknowledgments: The authors express their gratitude to Coordination for the Improvement of Higher Education Personnel (CAPES), National Council of Scientific and Technological Development (CNPq), Foundation of Research Support of Minas Gerais State (FAPEMIG). 
Conflicts of Interest: Conflicts of Interest: The authors declare no conflict of interest. The funders had no role in the design of the study; in the collection, analyses, or interpretation of data; in the writing of the manuscript, or in the decision to publish the results.

\section{REFERENCES}

1. Petrini O. Fungal endophytes of tree leaves. In: Andrews JH, Hirano SS, editors. Microbial Ecology of leaves. New York: Springer; 1991. p. 179-197.

2. Azevedo JL, Maccheroni JrW, Pereira JO, Araújo WL. Endophytic microorganisms: a review on insect control and recent advances on tropical plants. Electron J Biotechnol. 2000 Apr;3(1):15-6. doi:10.2225/vol3-issue1-fulltext-4.

3. Sudha V, Govindaraj R, Baskar K, AI-Dhabi NA, Duraipandiyan V. Biological properties of endophytic fungi. Braz Arch Biol Technol. 2016 Dec;59:e16150436. doi:10.1590/1678-4324-2016150436

4. Bongiorno VA, Rhoden AS, Garcia A, Polonio JC, Azevedo JL, Pereira JO, et al. Genetic diversity of endophytic fungi from Coffea arabica cv. IAPAR-59 in organic crops. Ann Microbiol. 2016 Oct;66:855-65. doi: 10.1007/s13213-015-1168-0.

5. Oliveira RJV, Souza RG, Lima TEF, Cavalcanti MAQ. Endophytic fungal diversity in coffee leaves (Coffea arabica) cultivated using organic and conventional crop management systems. Mycosphere. 2014 Aug;5(4):523-530. doi:10.5943/mycosphere/5/4/4.

6. Santamaría J, Bayman P. Fungal epiphytes and endophytes of coffee leaves (Coffea arabica). Microbial Ecol. 2005 Aug;50(1):1-8. doi:10.1007/s00248-004-0002-1.

7. Vega FE, Posada F, Peterson SW, Gianfagna TJ, Chaves F. Penicillium species endophytic in coffee plants and ochratoxin A production. Mycol. 2006 Jan;98(1):31-42. doi:10.3852/mycologia.98.1.31

8. Vega FE, Posada F, Aime MC, Pava-Ripoll M, Infante F, Rehner AS. Entomopathogenic fungal endophytes. Biol Control. 2008 Jan;46(1):72-8. doi:10.1016/j.biocontrol.2008.01.008.

9. Vega FE, Simpkins A, Aime MC, Posada F, Peterson SW, Rehner SA. Fungal endophyte diversity in coffee plants from Colombia, Hawai'i, Mexico and Puerto Rico. Fungal Ecol. 2010 Aug;3(3):122-38. doi:10.1016/j.funeco.2009.07.002.

10. Silva ÍW, Ribeiro LH, Gorri JER, Alves FM, Fernandes FL. First report on the leafminer fly Lyriomiza trifolii (Diptera: Agromizydae) attacking coffee plantations. Coffee Sci. 2015 Mar;10(2):262-65.

11. Carvalho DC, Brigagão MRPL, Santos MH, Paula FBA, Giusti-Paiva A, Azevedo L. Organic and conventional Coffea arabica L.: a comparative study of the chemical composition and physiological, biochemical and toxicological effects in wistar rats. Plant Foods Hum Nutr. 2011 Jan;66(2):114-21. doi:10.1007/s11130-011-02219.

12. Ding $\mathrm{CH}$, Wang QB, Guo S, Wang ZY. The improvement of bioactive secondary metabolites accumulation in Rumex gmelini Turcz through co-culture with endophytic fungi. Braz J Microbiol. 2018 Nov;49(2):362-69. doi:10.1016/j.bjm.2017.04.013.

13. Rajamanikyam M, Vadlapudi V, Upadhyayula SM. Endophytic fungi as novel resources of natural therapeutics. Braz Arch Biol Technol. 2017 Aug;60:e17160542. doi:10.1590/1678-4324-2017160542.

14. Kusari S, Singh S, Jayabaskaran C. Rethinking production of Taxol ${ }^{\circledR}$ (paclitaxel) using endophyte biotechnology. Trends Biotechnol. 2014 May;32(6):304-11. doi:10.1016/j.tibtech.2014.03.011.

15. Nisa H, Kamili AN, Nawchoo IA, Shafi S, Shameem N, Bandh AS. Fungal endophytes as prolific source of phytochemicals and other bioactive natural products: a review. Microb Pathog. 2015 Apr;82:50-9. doi:10.1016/j.micpath.2015.04.001.

16. Dutta D, Puzari KC, Gogoi R, Dutta P. Endophytes: exploitation as a tool in plant protection. Braz Arch Biol Technol. 2014 Oct;57(5):621-29. doi:10.1590/S1516-8913201402043.

17. Qadri M, Nalli Y, Jain SK, Chaubey A, Ali A, Strobel GA, et al. An insight into the secondary metabolism of Muscodor yucatanensis: small-molecule epigenetic modifiers induce expression of secondary metabolism-related genes and production of new metabolites in the endophyte. Microb Ecol. 2017 May;73(4):954-65. doi:10.1007/s00248-016-0901-y.

18. Strobel G, Daisy B, Castillo U, Harper J. Natural products from endophytic microorganisms. J Nat Prod. 2004 Feb;67(2):257-68. doi:10.1021/np030397v.

19. Sunitha VH, Devi DN, Srinivas C. Extracellular enzymatic activity of endophytic fungal strains isolated from medicinal plants. World J Agric Sci. 2013 Apr;9(1):01-9. doi:10.5829/idosi.wjas.2013.9.1.72148.

20. Bezerra JDP, Santos MGS, Svedese VM, Lima DMM, Fernandes MJS, Paiva LM, et al. Richness of endophytic fungi isolated from Opuntia ficus-indica Mill. (Cactaceae) and preliminary screening for enzyme production. World J Microbiol Biotechnol. 2012 May;28(5):1989-95. doi:10.1007/s11274-011-1001-2. 
21. Bischoff KM, Wicklow DT, Jordan DB, Rezende ST, Liu S, Hughes SR, et al. Extracellular hemicellulolytic enzymes from the maize endophyte Acremonium zeae. Curr Microbiol. 2009 May;58(5):499-503. doi:10.1007/s00284-008-9353-z.

22. Desire MH, Bernard F, Forsah MR, Assang CT, Denis ON. Enzymes and qualitative phytochemical screening of endophytic fungi isolated from Lantana camara Linn. leaves. J Appl Biol Biotechnol. 2014 Dec;2(6):001-06. doi:10.7324/JABB.2014.2601.

23. Onofre SB, Mattiello SP, Silva GC, Groth D, Malagi I. Production of cellulases by the endophytic fungus Fusarium oxysporum. J Microbiol Res. 2013 Aug;3(4):131-34. doi:10.5923/j.microbiology.20130304.01.

24. Samarakoon MC, Thongbai B, Hyde KD, Brönstrup M, Beutling U, Lambert et al. Elucidation of the life cycle of the endophytic genus Muscodor and its transfer to Induratia in Induratiaceae fam. nov., based on a polyphasic taxonomic approach. Fungal Divers. 2020 Mar;101:177-210. doi:10.1007/s13225-020-00443-9.

25. Monteiro MCP, Alves NM, de Queiroz MV, Pinho DB, Pereira OL, Souza AMC, et al. Antimicrobial activity of endophytic fungi from coffee plants. Biosci J. 2017 Apr;33(2):381-89. doi: 10.14393/BJ-v33n2-34494.

26. Strobel GA, Dirkse E, Sears J, Markworth C. Volatile antimicrobials from Muscodor albus, a novel endophytic fungus. Microbiol. 2001 Nov;147(11):2943-50. doi:10.1099/00221287-147-11-2943.

27. Hankin L, Anagnostakis SL. The use of solid media for detection of enzyme production by fungi. Mycol. 1975 Jun;67(3):597-606. doi:10.2307/3758395.

28. Miller GL. Use of dinitrosalicylic acid reagent for determination of reducing sugar. Anal Chem. 1959 Mar;31(3):426-28. doi:10.1021/ac60147a030.

29. Lever M. A new reaction for colorimetric determination of carbohydrates. Anal Biochem. 1972 Nov;47(1):273-79. doi:10.1016/0003-2697(72)90301-6.

30. Bradford MM. A rapid and sensitive method for the quantitation of microgram quantities of protein utilizing the principle of protein-dye binding. Anal Biochem. 1976 Dec;72(1-2):248-54. doi:10.1016/0003-2697(76)90527-3.

31. Scott AJ, Knott M. A cluster analysis method for grouping means in the analysis of variance. Biometrics. 1974 Sep;30(3):507-12.

32. Ten LN, Im WT, Kim MK, Kang MS, Lee ST. Development of a plate technique for screening of polysaccharidedegrading microorganisms by using a mixture of insoluble chromogenic substrates. J Microbiol Meth. 2014 Mar;56(3):375-82. doi:10.1016/j.mimet.2003.11.008.

33. Mehta A, Bodh U, Gupta R. Fungal lipases: a review. J Biotech Res. 2017 May;8(1):58-77.

34. Nwuche CO, Ogbonna JC. Isolation of lipase producing fungi from palm oil mill effluent (POME) dump sites at Nsukka. Braz Arch Biol Technol. 2011 Feb;54(1):113-16. doi:10.1590/S1516-89132011000100015.

35. Carneiro LABC, Costa-Silva TA, Souza CRF, Bachmann L, Oliveira WP, Said S. Immobilization of lipases produced by the endophytic fungus Cercospora kikuchii on chitosan microparticles. Braz Arch Biol Technol. 2014 Aug;57(4):578-586. doi:10.1590/S1516-8913201402174.

36. Savitha S, Sadhasivam S, Swaminathan K, Lin FH. Fungal protease: production, purification and compatibility with laundry detergents and their wash performance. J Taiwan Inst Chem Eng. 2011 Mar;42(2):298-304. doi:10.1016/j.jtice.2010.05.012.

37. Burhan A, Nisa U, Gokhan C, Omer C, Ashabil A, Osman G. Enzymatic properties of a novel thermostable, thermophilic, alkaline and chelator resistant amylase from an alkalophilic Bacillus sp. isolate ANT-6. Process Biochem. 2003 May;38(10):1397-403. doi:10.1016/S0032-9592(03)00037-2.

38. Pandey A, Nigam P, Soccol CR, Soccol VT, Singh D, Mohan R. Advances in microbial amylases. Biotechnol Appl Biochem. 2000 Apr;31(2):135-52. doi:10.1042/ba19990073.

39. Alves NM, Guimarães LHS, Piccoli RH, Cardoso PG. Production and partial characterization of an extracellular phytase produced by Muscodor sp. under submerged fermentation. Adv Microbiol. 2016 Dec;6(01):23-32. doi:10.4236/aim.2016.61003.

40. Wang $\mathrm{Y}$, Gao X, Su Q, Wu W, An L. Expression of heat stable phytase from Aspergillus fumigatus in tobacco (Nicotiana tabacum L. cv. NC89). Ind J Biochem Biophys. 2007 Jan;44(1):26-30.

41. Hamada A, Yamaguchi K, Ohnishi N, Harada M, Nikumaru S, Honda H. High-level production of yeast (Schwanniomyces occidentalis) phytase in transgenic rice plants by a combination of signal sequence and codon modification of the phytase gene. Plant Biotechnol J. 2005 Jan;3(1):43-55. doi:10.1111/j.14677652.2004.00098.x.

42. Garg G,Singh A, Kaur A, Singh R, Kaur J, Mahajan R. Microbial pectinases: an ecofriendly tool of nature for industries. 3 Biotech. 2016 Jan;6(1):47. doi:10.1007/s13205-016-0371-4.

43. Martin N, Souza SRD, Silva RD, Gomes E. Pectinase production by fungal strains in solid-state fermentation using agro-industrial bioproduct. Braz Arch Biol Technol. 2004 Sep;47(5):813-9. doi:10.1590/S151689132004000500018. 
44. Schluz B, Wark U, Draeyger S, Aust HJ. Endophytes from herbaceous plants and shrubs, effectiveness of surface sterilization methods. Mycol Res. 1993 Dec;97(12):1447-50. doi:10.1016/S0953-7562(09)80215-3.

45. Sajith S, Priji P, Sreedevi S, Benjamin S. An overview on fungal cellulases with an industrial perspective. J Nutr Food Sci. 2016 Jan;6(1):461.

46. Kubicek CP, Mikus M, Schuster A, Schmoll M, Seiboth B. Metabolic engineering strategies for the improvement of cellulase production by Hypocrea jecorina. Biotechnol Biofuels. 2009 Sep;2(1), 19. doi:10.1186/1754-6834-219.

47. Kuhad RC, Gupta R, Singh A. Microbial cellulases and their industrial applications. Enzyme Res. 2011 Sep;2011:280696. doi:10.4061/2011/280696.

48. Zhang Z, Wang M, Gao R, Yu X, Chen G. Synergistic effect of thermostable $\beta$-glucosidase TN0602 and cellulase on cellulose hydrolysis. 3 Biotech. 2017 May;7(1):54. doi:10.1007/s13205-017-0672-2.

49. Kasana RC, Salwan R, Dhar H, Dutt S, Gulati A. A rapid and easy method for the detection of microbial cellulases on agar plates using gram's iodine. Curr Microbiol. 2008 Sep;57(5):503-7. doi:10.1007/s00284-008-9276-8.

50. Mercier J, Jiménez Jl. Control of fungal decay of apples and peaches by the biofumigant fungus Muscodor albus. Postharvest Biol Tec. 2004 Jan;31(1):1-8. doi:10.1016/j.postharvbio.2003.08.004.

51. Mercier J, Manker DC. Biocontrol of soil-borne diseases and plant growth enhancement in greenhouse soilless mix by the volatile-producing fungus Muscodor albus. Crop Prot. 2005 Apr;24(4):355-62. doi:10.1016/j.cropro.2004.09.004.

52. Mercier J, Jiménez-Santamaría JI, Tamez-Guerra P. Development of the volatile-producing fungus Muscodor albus Worapong, Strobel, and Hess as a novel antimicrobial biofumigant. Rev Mex Fitopatol. 2007 Jul;25(2):1739.

53. Stinson M, Ezra D, Hess WM, Sears J, Strobel G. An endophytic Gliocladium sp. of Eucryphia cordifolia producing selective volatile antimicrobial compounds. Plant Sci. 2003 Oct;165(4):913-22. doi:10.1016/S01689452(03)00299-1.

54. Strobel G. Muscodor Albus and its biological promise. J Ind Microbiol Biotechnol. 2006 Jul;33(7):514-22. doi:10.1007/s10295-006-0090-7.

55. Strobel G. Muscodor species-endophytes with biological promise. Phytochemistry Rev. 2011 Feb;10(2):165-72. doi:10.1007/s11101-010-9163-3.

56. Suwannarach N, Kumla J, Bussaban B, Hyde KD, Matsui K, Lumyong S. Molecular and morphological evidence support four new species in the genus Muscodor from Northern Thailand. Ann Microbiol. 2013 Jan;63(4):134151. doi:10.1007/s13213-012-0593-6.

57. Worapong J, Strobel GA. Biocontrol of a root rot of kale by Muscodor albus strain MFC2. BioControl. 2009 Jun;54(2):301-6. doi:10.1007/s10526-008-9175-8.

58. Zhang CL, Wang GP, Mao LJ, Komon-Zelazowska M, Yuan ZL, Lin FC. Muscodor fengyangensis sp. nov. from Southeast China: morphology, physiology and production of volatile compounds. Fungal Biol. 2010 Oct;114(10):797-808. doi:10.1016/j.funbio.2010.07.006.

59. Hongsanan $\mathrm{S}$, Hyde KD, Bahkali $\mathrm{AH}$, Camporesi E, Chomnunti $\mathrm{P}$, Ekanayaka $\mathrm{H}$, et al. Fungal biodiversity profiles 11-20. Cryptogamie Mycol. 2015 Aug;36:355-80. doi:10.7872/crym/v36.iss3.2015.355.

60. Saikkonen K, Wälli P, Helander M, Faeth SH. Evolution of endophyte-plant symbioses. Trends Plant Sci. 2004 Jun;9(6):275-80. doi:10.1016/j.tplants.2004.04.005.

(C) 2020 by the authors. Submitted for possible open access publication under the terms and conditions of the Creative Commons Attribution (CC BY NC) license (https://creativecommons.org/licenses/by-nc/4.0/). 